\title{
Modeling enablers for sustainable logistics collaboration integrating - Canadian and Polish perspectives
}

\author{
Katarzyna Grzybowska \\ Poznan University of Technology, \\ Strzelecka 11, 60-965 Poznan, Poland \\ Email: \\ katarzyna.grzybowska@put.poznan.pl
}

\author{
Anjali Awasthi \\ Concordia University, \\ 1455 De Maisonneuve Blvd. West \\ Montreal H3G 1M8, Canada \\ Email: \\ awasthi@ciise.concordia.ca
}

\author{
Mohammad Hussain \\ Concordia University, \\ 1455 De Maisonneuve Blvd. \\ West \\ Montreal H3G 1M8, Canada \\ Email: \\ whozane@gmail.com
}

\begin{abstract}
Collaboration planning is vital for achieving sustainable logistics. In this paper, we present an ISM based approach for modeling enablers for sustainable logistics collaboration integrating Canadian and Polish perspectives. Enablers can be defined as the key elements (or drivers) for achieving successful collaboration. A comprehensive literature review is conducted to identify 17 enablers for sustainable logistics collaboration. Based on these enablers, a questionnaire study is conducted with 20 logistics experts in Canada and Poland to identify their importance. Based on the aggregated expert ratings, an Interpretive Structural Model (ISM) is developed to identify the relationships among the various enablers. The results of our study show that not all enablers to sustainability collaboration between logistics partners require the same amount of attention. This classification will help Supply Chain managers to help them to focus on those variables that are most important for the transformation of collaboration between logistics partners.
\end{abstract}

\section{INTRODUCTION}

$\mathrm{C}$ OLLABORATION is vital to achieving success in sustainable logistics operations. Modern logistics operators are under increased pressure and administrative regulations in order to fulfill environmental objectives, reduce congestion and make parking space available for public space. For example, vehicle timing, access and sizing regulations are limiting the areas, timing and size of delivery vehicles. Likewise, tax rebate policies may encourage the use of clean energy vehicles or energy efficient goods distribution practices. Under these conditions, collaboration seems a logical and viable strategy for many logistics operators to achieve operational performance as well as successfully meet environmental targets. Several researchers emphasize the importance of collaboration in value creation in supply chains [1]; [2]; [3]. Langley [4] advocates that with the complexity and dynamic nature of today's rapidly evolving business world, any firm stands to lose if trying to "go it alone." [5]. Barratt [6] addresses supply chain collaboration through customer buying behavior and service needs, identifying elements that make up supply chain as

This work is supported by Poznan University of Technology and Concordia University well as investigate the interrelationships among the cultural, strategic and implementation elements of supply chain. Cassivi, Garner Group, Ovalle and Márquez (2003) present e-collaboration tools for supply chains [7], [8], [9]. Holweg et al. [10] classify collaboration initiatives using conceptual water-tank approach; and discuss their dynamic behaviors and key characteristics. Kale et al. [11] investigate internetbased collaborative transportation networks. Muckstadt et al. propose guidelines for collaborative supply chain system design and operation [12]. Zhou et al. investigate strategic alliance in freight consolidation [13].

Supply chain management is defined as "the systemic, strategic coordination of the traditional business functions and the tactics across these business functions within a particular company and across businesses within the supply chain, for the purposes of improving the long term performance of the individual companies and the supply chain as a whole" [14]. Supply chain structure defines the way various organizations within the supply chain are arranged and related to each other. The supply chain structure falls into four main types: Convergent: each node in the chain has at least one successor and several predecessors. Divergent: each node has at least one predecessor and several successors. Conjoined: which is a combination of each convergent chain and one divergent chain. Network: which cannot be classified as convergent, divergent or conjoined, and is more complex than the three previous types $[15,16,17]$.

In this paper, our research objectives are:

- to identify and rank the enablers for collaboration between logistics partners in the context of Poland and Canada

- to find out the relation and interaction among identified enablers using ISM

- to suggest for future research.

The paper is organized as follows. In section 2, we will present a list of enablers aimed at the identification of cooperation between business partners. A brief characteristic of questionnaire, the ISM methodology along with its application will be covered in sections 3-5. The MICMAC analysis will be presented in section 6 . Finally, the article will 
end with a recapitulation which includes the most important conclusions and directions for future works in sections 7-8.

\section{IDENTIFICATION OF ENABLERS FOR COLLABORATION BETWEEN LOGISTICS PARTNERS}

An enabler is defined as "as one that enables another to achieve an end" where enable implies to make able; give power, means, competence, or ability to (Merriam-Webster). An enabler is considered as a variable that enables (ability to) the attainment of the Sustainable Supply Chain. This definition is consistent with the use of the term enabler in ISM models [18], growth enablers in construction companies [18], information technology (IT) enablement in the Supply Chain [20], enablers of reverse logistics [21], supply chain performance measurement system implementation [22], modelling the barriers of global supply chain [23], supply chain sustainability - analysing the enablers [24].

On the basis of the literature as well as the experience and knowledge of experts, enablers were proposed for collaboration between logistics partners. 17 important variables (enablers), have been differentiated, which, in the opinion of experts, are of significance in business cooperation. Enablers, discussed and selected for analysis, are presented below.

\section{A. INFORMATION SHARING}

Information sharing among logistics partners can take place about anything that leads to amelioration of operational efficiency and attainment of environmental objectives. For example, customer demands, vehicle resources, warehousing capacity, goods inventory or technological know-how. Information sharing leads to visibility in supply chains which in turn leads to cooperation among supply chain partners.

\section{B. COORDINATION}

Coordination can be defined as alignment of project objectives and resources in order to achieve the successful collaboration. Effective coordination among all enterprises cooperating with one another in supply chain is essential to its success [25]. Lee and Whang suggested that information is a basic enabler for tight coordination [26]. Coordination allows for the efforts and the aims of the individual enterprises to be unified. The coordinating actions are fundamental, those that (1) stimulate the supply chain through the creation of a supply chain growth concept, (2) regulate the supply chain by redistributing the possessed resources (3) integrate the supply chain by linking resources, monitoring and an assessment of the actions [27].

\section{TRUST}

In a supply chain, trust is one of the key cooperation factors (e.g. trust that a supplier or a subcontractor perform their duties according to specifications; trust that a supplier with which the enterprise did cooperate previously, will supply a product of a proper quality; trust that the customer will pay within agreed period of time and will not cause a payment gridlock, etc) [28]. It is during cooperation when complex trustbased reactions occur, since one entity's gains depend on the other. The risk and uncertainty connected with trust and cooperation develop as the number of participants increases.

\section{WILLINGNESS TO COLLABORATE}

Willingness to collaborate is vital in achieving successful collaboration. Disinterested partners lack commitment and may leave the collaboration anytime leading to waste of resources, time, money and personnel.

\section{E. COMMUNICATION}

According to Hahn et al. effective communication among all elements of supply chain. Clearly communicated goals across members of all hierarchy in the organization leads to efficient realization of planned objectives under given time, pressure and resources [25].

\section{F. COMMON BUSINESS GOALS}

Common business goals are one of the main reasons behind any organization's interest to collaborate with other partner organizations. Similar business goals lead to common practices, techniques, and efficient sharing of knowledge leading to win-win situation for all the organizations participating in collaboration.

\section{G. RESPONSIBILITY SHARING}

Responsibility allocation and sharing among the participating organizations leads to increased trust, information sharing, and commitment from the involved partners and fosters strong collaboration.

\section{H. PLANNING OF SUPPLY CHAIN ACTIVITIES}

Efficient and timely planning of supply chain activities reduces waste of time, resources and money arising from last minute changes in customer demands or unstable market conditions. For successful collaboration, right planning also leads to efficient realization of goals, sharing of resources, and profit allocation.

\section{FLEXIBILITY}

Organizations participating in any collaboration do not always have the same experience, culture, technological readiness, or brand image. Under these situations, it is vital for participating organizations to be flexible to adapt to others needs for joint success. Richey et al. identify technology and flexibility as key enablers for logistics collaboration [29].

\section{J. BENEFIT SHARING}

Benefit sharing among participants is vital for retaining loyalty towards collaboration. Benefit sharing can be done 
equally among partners or depending upon the stakes of major contributing organizations after mutual consensus.

\section{K. JOINT DECISION MAKING}

All the organizations involved in collaboration should work together and perform joint decision making to achieve operational and environmental goals. This will lead to increased trust and commitment which is essential for long term success of any collaboration.

\section{ORGANIZATIONAL CULTURE}

Organizational culture is very important in sharing of common vision and goals for any collaboration. Participating organizations should have a good understanding of other participant organizations culture to avoid any misconceptions and gaps that can serve as barriers in realization of project objectives.

\section{ORGANIZATIONAL COMPATIBILITY}

Organizational compatibility in terms of product-service types, size, location, strategy, employee culture, technology, management commitment, budget, resources etc. aids in developing successful collaborations among the participating organizations.

\section{N. RESOURCE SHARING (INTEGRATION)}

Once organizations enter into collaboration, it is important to address the goals of all participants efficiently, uniformly and in time either through partial and/or complete sharing of resources. This will also help in achieving successful project co-ordination and completion.

\section{O. TOP MANAGEMENT SUPPORT}

Commitment from management includes an effort and financial backing from the upper management to implement sustainability in logistics operations. Top management commitment retains employee interests in implementing sustainability practices and continuous improvement goals [30]. In order to achieve long term success, management support and commitment is very important and should be accompanied with employee rewards and training programs.

\section{P. TECHNOLOGICAL READINESS}

Use of IT tools to monitor the supply chains and sharing information among the partners leads to visibility in supply chain, thereby providing better cooperation among different levels of the supply chain [30]. Electronic data interchange and internet have enabled partners in supply chains to act upon same data rather than rely on distorted and noisy data that emerges in an extended supply chain [26, 31]. Swafford et al emphasize the role of IT integration and flexibility in achieving supply chain agility [32].

\section{Q. TRAINING}

Training helps employees with expertise to perform their tasks efficiently. Company's power comes from the physical and mental strength of their workers. Organizing employee trainings and maintaining occupational safety and health are among the main functions of human resources management departments. These two functions interact and they both serve the aim of protecting employee's physical, psychological and social health [30].

\section{QUESTIONNAIRE-BASED SURVEY}

In order to determine the relative importance of enablers, we conducted a questionnaire study. The main objective of the questionnaire-based survey was to facilitate experts in developing a relationship matrix as a first step towards developing an ISM-based model. In this survey the respondents were asked to indicate the importance of 17 listed enablers on a five-point Likert scale [18]. On this scale, 1 and 5 correspond to 'very low importance' to 'very high importance', respectively. In total, questionnaires were sent to 20 experts in Poland and Canada. All of them were analyzed.

TABLE I.

ENABLERS ACCORDING TO RESEARCHERS FROM POLAND

\begin{tabular}{|c|c|c|}
\hline lp. & Enablers & Mean score \\
\hline 1 & Communication & 4,6 \\
\hline 2 & Information sharing & 4,6 \\
\hline 3 & Coordination & 4,4 \\
\hline 4 & Willingness to collaborate & 4,3 \\
\hline 5 & Planning of supply chain activities & 4,1 \\
\hline 6 & Trust & 4,0 \\
\hline 7 & Responsibility sharing & 3,9 \\
\hline 8 & Common business goals & 3,8 \\
\hline 9 & Benefit sharing & 3,6 \\
\hline 10 & Flexibility & 3,4 \\
\hline 11 & Joint Decision Making & 3,4 \\
\hline 12 & Resource sharing (integration) & 3,4 \\
\hline 13 & Organisational compatibility & 3,3 \\
\hline 14 & Organizational culture & 3,3 \\
\hline 15 & Top management support & 3,1 \\
\hline 16 & Technological readiness & 2,5 \\
\hline 17 & Training & 2,5 \\
\hline
\end{tabular}

Tables 1-2 show the difference between perceiving the relevance of the enablers in relation to the collaboration between business partners in Poland and Canada. According to researchers from Poland (Tab. 1), the most significant enabler is communication $(4,6)$. The lack of information often leads to misunderstandings, and these, in turn, cause uncertainty, ambiguity, difficulty and failure in communication, and in effect failure in collaboration between business organizations. 
TABLE III.

ENABLERS ACCORDING TO RESEARCHERS FROM CANADA

\begin{tabular}{llc}
\hline Ip. & Enablers & Mean score \\
\hline $\mathbf{1}$ & Trust & 4,4 \\
$\mathbf{2}$ & Coordination & 4,3 \\
$\mathbf{3}$ & Information sharing & 4,3 \\
$\mathbf{4}$ & Common business goals & 4,3 \\
$\mathbf{5}$ & Flexibility & 4,1 \\
$\mathbf{6}$ & Willingness to collaborate & 4,1 \\
$\mathbf{7}$ & Organizational culture & 4,0 \\
$\mathbf{8}$ & Organisational compatibility & 3,9 \\
$\mathbf{9}$ & Joint Decision Making & 3,9 \\
$\mathbf{1 0}$ & Responsibility sharing & 3,9 \\
$\mathbf{1 1}$ & Technological readiness & 3,9 \\
$\mathbf{1 2}$ & Communication & 3,7 \\
$\mathbf{1 3}$ & Benefit sharing & 3,7 \\
$\mathbf{1 4}$ & Resource sharing (integration) & 3,7 \\
$\mathbf{1 5}$ & Training & 3,7 \\
$\mathbf{1 6}$ & Planning of supply chain activities & 3,6 \\
$\mathbf{1 7}$ & Top management support & 3,4 \\
\hline & & \\
\hline
\end{tabular}

TABLE IIIII.

ENABLERS APPLIED IN THE RESEARCH

\begin{tabular}{llc}
\hline $\mathbf{l p .}$ & Enablers & Mean score \\
\hline $\mathbf{1}$ & Information sharing & 4,45 \\
$\mathbf{2}$ & Coordination & 4,35 \\
$\mathbf{3}$ & Trust & 4,20 \\
$\mathbf{4}$ & Willingness to collaborate & 4,20 \\
$\mathbf{5}$ & Communication & 4,15 \\
$\mathbf{6}$ & Common business goals & 4,05 \\
$\mathbf{7}$ & Responsibility sharing & 3,90 \\
$\mathbf{8}$ & Planning of supply chain activities & 3,85 \\
$\mathbf{9}$ & Flexibility & 3,75 \\
$\mathbf{1 0}$ & Benefit sharing & 3,65 \\
$\mathbf{1 1}$ & Joint Decision Making & 3,65 \\
\hline $\mathbf{1 2}$ & Organizational culture & 3,65 \\
$\mathbf{1 3}$ & Organisational compatibility & 3,60 \\
\hline $\mathbf{1 4}$ & Resource sharing (integration) & 3,55 \\
\hline $\mathbf{1 5}$ & Top management support & 3,25 \\
\hline $\mathbf{1 6}$ & Technological readiness & 3,20 \\
\hline $\mathbf{1 7}$ & Training & 3,10 \\
\hline & &
\end{tabular}

While researchers from Canada (Tab. 2) deemed trust $(4,4)$ as key in proper collaboration. Practically each commercial transaction contains an element of trust. Trust has its practical, real, economic value, since it results in the increase in the effectiveness of the system and allows for more goods to be produced.

The explanation of the occurring differences is cultural differences - different behaviors, social norms or a different system of values. Despite the fact that social, political, economic changes as well as technological achievements have made inter-cultural contacts become an everyday matter, cultural differences still take place and play a significant role in the 21 st century.

Table 3 includes the joint list of enablers, which was accepted in the research and analysis.

\section{Methodology}

Interpretive Structural Modeling (ISM) is defined as a process aimed at assisting the human being to better understand and clearly recognize what one does not know [33]. The ISM process transforms unclear, poorly articulated mental models of systems into visible and well defined models. ISM is an interactive learning process. In this technique, a set of different directly and indirectly related elements are structured into a comprehensive systematic model. The model so formed portrays the structure of a complex issue or problem in a carefully designed pattern implying graphics as well as words [18, 34].

Interpretive Structural Modeling was first proposed by Warfield [35]. It enables individuals or groups to develop a map of the complex relationships between many elements involved in a complex decision situation [22].

\section{A. THE IMPORTANT CHARACTERISTICS OF ISM}

The important characteristics of ISM are:

- This methodology is interpretive, as the judgment of the group decides whether and how the different elements are related.

- It is structural on the basis of mutual relationships as the overall structure is extracted from the complex set of elements.

- It is a modelling technique, as the specific relationships and overall structure are portrayed in a digraph model [34].

\section{B. THE VARIOUS STEPS INVOLVED IN THE ISM TECHNIQUE}

The steps involved in the ISM are represented in the form of a flow diagram (see Fig. 1).

The various steps involved in the ISM technique are as follows [18]:

Step 1: Different enablers (or variables), which are related to defined problems, are identified.

Step 2: A Structural Self-Interaction Matrix (SSIM) is developed for enablers. This matrix indicates the pair-wise relationship among enablers of the system. This matrix is checked for transitivity.

Step 3: A Reachability Matrix (RM) is developed from the SSIM.

Step 4: The RM is partitioned into different levels. 


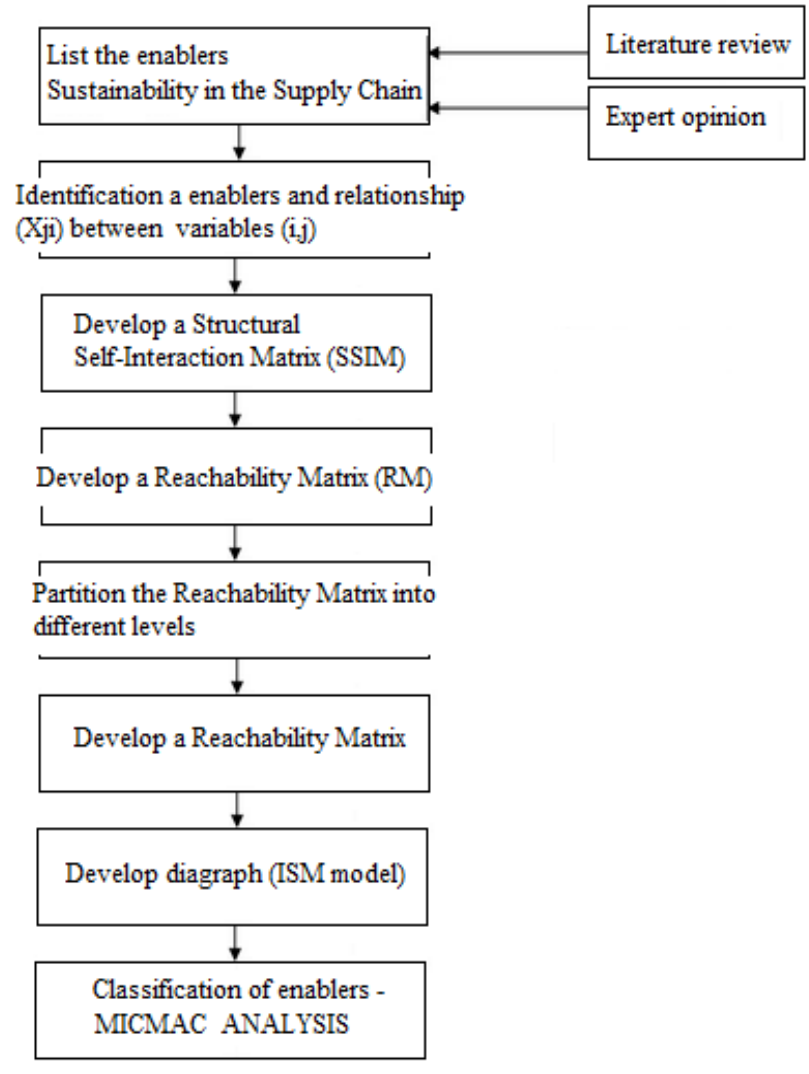

Fig. 1 Flow diagram for constructing an Interpretive Structural Modeling; based on [35]

Step 5: The Reachability Matrix is converted into its conical form, i.e. with most zero (0) elements in the upper diagonal half of the matrix and most unitary (1) elements in the lower half.

Step 6: Based upon the above, a directed graph (digraph) is drawn and transitivity links are removed.

Step 7: Digraph is converted into an ISM model by replacing nodes of the elements with statements.

Step 8: The ISM model is checked for conceptual inconsistency and necessary modifications are incorporated.

\section{THE FORMATION OF STRUCTURAL SELF-INTERACTION MATRIX (SSIM)}

After identifying the 17 enablers through the review of literature and expert opinions, the next step is to analyze these enablers. For this purpose, a contextual relationship of "leads to" type is chosen. Bearing the contextual relationship for each enabler in mind, the existence of a relation between any two enablers ( $i$ and $j$ ) and the associated direction of this relation has been decided [18].

From the enablers identified in step 1, a contextual relationship is identified among enablers with respect to which pairs of variables would be examined. This step transforms the list into a matrix and marks dependencies using expert opinions. After resolving the enablers set under consideration and the contextual relation, a Structural SelfInteraction Matrix (SSIM) is prepared.

Four symbols are used to denote the direction of relationships between the enablers ( $i$ and $j$ ):

- $\mathrm{V}$ : for the relationship from enabler $\mathrm{i}$ to enabler $\mathrm{j}$ and not in both directions;

- A: for the relationship from enabler $\mathrm{j}$ to enabler $\mathrm{i}$ and not in both directions;

- $\mathrm{X}$ : for both the directional relationships from enabler $\mathrm{i}$ to enabler $\mathrm{j}$ and $\mathrm{j}$ to $\mathrm{i}$;

- O: if the relationships between the enablers did not appear valid (enablers $\mathrm{i}$ and $\mathrm{j}$ are unrelated) [18].

TABLE IVV.

Structural Self-InTERActive Matrix (SSIM)

\begin{tabular}{|c|c|c|c|c|c|c|c|c|c|c|c|c|c|c|c|c|c|}
\hline lp. & Enablers. & 17 & 16 & 15 & 14 & 13 & 12 & 11 & 10 & 9 & 8 & 7 & 6 & 5 & 4 & 3 & 2 \\
\hline 1 & Information sharimg & $\mathrm{x}$ & A & $\mathrm{v}$ & $\mathrm{x}$ & $\mathrm{x}$ & $\mathrm{v}$ & A & 0 & 0 & $\mathrm{v}$ & $\mathrm{x}$ & A & $\mathrm{x}$ & $\mathrm{v}$ & $\mathrm{x}$ & $\mathrm{x}$ \\
\hline 2 & Coordination & A & A & $\mathrm{v}$ & $\mathrm{x}$ & $\mathrm{x}$ & $\mathrm{v}$ & 0 & 0 & $\mathrm{x}$ & $\mathrm{x}$ & A & 0 & $\mathrm{x}$ & $\mathrm{v}$ & 0 & \\
\hline 3 & Trust & A & 0 & $\mathrm{v}$ & $\mathrm{x}$ & $\mathrm{x}$ & $\mathrm{v}$ & $\mathrm{x}$ & A & 0 & 0 & 0 & 0 & 0 & $\mathrm{v}$ & & \\
\hline 4 & Wallingness to collaborate & A & 0 & $\mathrm{v}$ & $\mathrm{v}$ & $\mathrm{x}$ & $\mathrm{v}$ & $\mathrm{x}$ & $\mathrm{x}$ & 0 & $\mathrm{x}$ & A & A & A & & & \\
\hline 5 & Communication & $\mathrm{x}$ & $\mathrm{x}$ & $\mathrm{v}$ & $\mathrm{x}$ & $\mathrm{x}$ & $\mathrm{v}$ & A & 0 & $\mathrm{v}$ & $\mathrm{x}$ & A & 0 & & & & \\
\hline 6 & Common busmess goals & A & 0 & $\mathrm{v}$ & $\mathrm{v}$ & $\mathrm{x}$ & $\mathrm{v}$ & A & A & 0 & 0 & $\mathrm{x}$ & & & & & \\
\hline 7 & Respensibility sharing & A & $\mathrm{v}$ & $\mathrm{x}$ & $\mathrm{x}$ & $\mathrm{x}$ & $\mathrm{v}$ & $\mathrm{x}$ & $\mathrm{x}$ & $\mathrm{v}$ & $\mathrm{v}$ & & & & & & \\
\hline 8 & Planning of supply chain activities & A & A & $\mathrm{v}$ & $\mathrm{v}$ & $\mathrm{x}$ & $\mathrm{v}$ & $\mathrm{v}$ & 0 & $\mathrm{x}$ & & & & & & & \\
\hline 9 & Flexibality & A & A & $\mathrm{v}$ & $\mathrm{v}$ & $\mathrm{x}$ & $\mathrm{v}$ & 0 & 0 & & & & & & & & \\
\hline 10 & Benefit sharing & 0 & 0 & $\mathrm{v}$ & $\mathrm{v}$ & $\mathrm{x}$ & $\mathrm{v}$ & $\mathrm{x}$ & & & & & & & & & \\
\hline 11 & Joint Decision Making & A & 0 & $\mathrm{v}$ & $\mathrm{x}$ & $\mathrm{x}$ & $\mathrm{v}$ & & & & & & & & & & \\
\hline 12 & Oxganizational culture & A & 0 & 0 & A & $\mathrm{x}$ & & & & & & & & & & & \\
\hline 13 & Organisational compatibility & 0 & $\mathrm{x}$ & $\mathrm{v}$ & $\mathrm{x}$ & & & & & & & & & & & & \\
\hline 14 & Resource sharing (imtegration) & A & $\mathrm{x}$ & $\mathrm{v}$ & & & & & & & & & & & & & \\
\hline 15 & Top management suppost & A & $\mathrm{v}$ & & & & & & & & & & & & & & \\
\hline 16 & Technological readiness & 0 & & & & & & & & & & & & & & & \\
\hline 17 & Training & & & & & & & & & & & & & & & & \\
\hline
\end{tabular}

Based on the review of literature and expert's responses, the SSIM is constructed as shown in Tab. 4. The following statements explain the use of symbols in Structural SelfInteraction Matrix, e.g. [18]:

- Symbol V is assigned to cell $(1,15)$ as enabler 1 influences or reaches enabler 15.

- Symbol A is assigned to cell $(2,17)$ as enabler 17 influences the enabler 2 .

- Symbol X is assigned to cell $(5,16)$ as enablers 5 and 16 influence each other.

- Symbol O is assigned to cell $(6,16)$ as enablers 6 and 16 are unrelated.

The next step is to develop the Reachability Matrix (RM) from the Structural Self-Interactive Matrix. This is obtained in two sub-steps.

In the first sub-step, the Structural Self-Interaction Matrix is trans-formed into a binary matrix (see Tab. 5), called the initial reachability matrix by substituting $\mathrm{V}, \mathrm{A}, \mathrm{X}, \mathrm{O}$ by 1 and 0 as per the case. The rules for the substitution of $1 \mathrm{~s}$ and Os are as follows:

- If the (i,j) entry in the SSIM is V, then the (i,j) entry in the reachability matrix becomes 1 and the $(j, i)$ entry becomes 0 . 
- If the $(i, j)$ entry in the SSIM is A, then the $(i, j)$ entry in the reachability matrix becomes 0 and the $(j, i)$ entry becomes 1 .

- If the $(i, j)$ entry in the SSIM is $X$, then the $(i, j)$ entry in the reachability matrix becomes 1 and the $(j, i)$ entry also becomes 1 .

- If the $(i, j)$ entry in the SSIM is $O$, then the $(i, j)$ entry in the reachability matrix becomes 0 and the $(j, i)$ entry also becomes 0 [18].

TABLE $\mathrm{V}$

INITIAL REACHABILITY MATRIX

\begin{tabular}{|l|l|l|l|l|l|l|l|l|l|l|l|l|l|l|l|l|l|l|}
\hline Ip. & Enablers & 1 & 2 & 3 & 4 & 5 & 6 & 7 & 8 & 9 & 10 & 11 & 12 & 13 & 14 & 15 & 16 & 17 \\
\hline 1 & Information sharing & 1 & 1 & 1 & 1 & 1 & 0 & 1 & 1 & 0 & 0 & 0 & 1 & 1 & 1 & 1 & 0 & 1 \\
\hline 2 & Coordination & 1 & 1 & 0 & 1 & 1 & 0 & 0 & 1 & 1 & 0 & 0 & 1 & 1 & 1 & 1 & 0 & 0 \\
\hline 3 & Trust & 0 & 0 & 1 & 1 & 0 & 0 & 0 & 0 & 0 & 0 & 1 & 1 & 1 & 1 & 1 & 0 & 0 \\
\hline 4 & Wallingness to collaborate & 0 & 0 & 0 & 1 & 0 & 0 & 0 & 1 & 0 & 1 & 1 & 1 & 1 & 1 & 1 & 0 & 0 \\
\hline 5 & Communication & 1 & 1 & 0 & 1 & 1 & 0 & 0 & 1 & 1 & 0 & 0 & 1 & 1 & 1 & 1 & 1 & 1 \\
\hline 6 & Common business goals & 1 & 0 & 0 & 1 & 0 & 1 & 1 & 0 & 0 & 0 & 0 & 1 & 1 & 1 & 1 & 0 & 0 \\
\hline 7 & Responsibility sharimg & 1 & 1 & 0 & 1 & 1 & 1 & 1 & 1 & 1 & 1 & 1 & 1 & 1 & 1 & 1 & 1 & 0 \\
\hline 8 & Planning of supply chain activities & 0 & 1 & 0 & 1 & 1 & 0 & 0 & 1 & 1 & 0 & 1 & 1 & 1 & 1 & 1 & 0 & 0 \\
\hline 9 & Elexibaity & 0 & 1 & 0 & 0 & 0 & 0 & 0 & 1 & 1 & 0 & 0 & 1 & 1 & 1 & 1 & 0 & 0 \\
\hline 10 & Benefit sharing & 0 & 0 & 1 & 1 & 0 & 1 & 1 & 0 & 0 & 1 & 1 & 1 & 1 & 1 & 1 & 0 & 0 \\
\hline 11 & Joint Decision Making & 1 & 0 & 1 & 1 & 1 & 1 & 1 & 0 & 0 & 1 & 1 & 1 & 1 & 1 & 1 & 0 & 0 \\
\hline 12 & Oxganizational culture & 0 & 0 & 0 & 0 & 0 & 0 & 0 & 0 & 0 & 0 & 0 & 1 & 1 & 0 & 0 & 0 & 0 \\
\hline 13 & Organisational compatibility & 1 & 1 & 1 & 1 & 1 & 1 & 1 & 1 & 1 & 1 & 1 & 1 & 1 & 1 & 1 & 1 & 0 \\
\hline 14 & Resource sharing (integration) & 1 & 1 & 1 & 0 & 1 & 0 & 1 & 0 & 0 & 0 & 1 & 1 & 1 & 1 & 1 & 1 & 0 \\
\hline 15 & Top management support & 0 & 0 & 0 & 0 & 0 & 0 & 1 & 0 & 0 & 0 & 0 & 0 & 0 & 0 & 1 & 1 & 0 \\
\hline 16 & Technological readimess & 1 & 1 & 0 & 0 & 1 & 0 & 0 & 1 & 1 & 0 & 0 & 0 & 1 & 1 & 0 & 1 & 0 \\
\hline 17 & Traiming & 1 & 1 & 1 & 1 & 1 & 1 & 1 & 1 & 1 & 0 & 1 & 1 & 0 & 1 & 1 & 0 & 1 \\
\hline
\end{tabular}

In the second sub-step, the final reachability matrix is prepared (see Tab. 6). The concept of transitivity is introduced so that some of the cells of the initial reachability matrix are filled by inference. The transitivity concept is used to fill the gap, if any, in the opinions collected during the development of the SSIM [18].

TABLE VI.

FINAL REACHABILITY MATRIX

\begin{tabular}{|c|c|c|c|c|c|c|c|c|c|c|c|c|c|c|c|c|c|c|}
\hline lp. & nablers & 1 & 2 & 3 & 4 & 5 & 6 & 7 & 8 & 9 & 10 & 11 & 12 & 13 & 14 & 15 & 16 & 17 \\
\hline 1 & Information sharing & 1 & 1 & 1 & 1 & 1 & 0 & 1 & 1 & 0 & 0 & 0 & 1 & 1 & 1 & 1 & 0 & 1 \\
\hline 2 & Coordination & 1 & 1 & 0 & 1 & 1 & 0 & 0 & 1 & 1 & 0 & 0 & 1 & 1 & 1 & 1 & 0 & $1^{*}$ \\
\hline 3 & \begin{tabular}{|l|} 
Trust \\
\end{tabular} & 0 & 0 & 1 & 1 & 0 & 0 & 0 & 0 & 0 & $1^{*}$ & 1 & 1 & 1 & 1 & 1 & $1^{*}$ & 0 \\
\hline 4 & Wallingness to cellaborate & 0 & 0 & $1^{*}$ & 1 & 0 & 0 & 0 & 1 & 0 & 1 & 1 & 1 & 1 & 1 & 1 & 0 & 0 \\
\hline 5 & Communication & 1 & 1 & 0 & 1 & 1 & 0 & 0 & 1 & 1 & 0 & 0 & 1 & 1 & 1 & 1 & 1 & 1 \\
\hline 6 & Common busimess goals & 1 & 0 & 0 & 1 & 0 & 1 & 1 & 0 & 0 & 0 & $1^{*}$ & 1 & 1 & 1 & 1 & $1^{*}$ & 0 \\
\hline 7 & Responsibility sharing & 1 & 1 & 0 & 1 & 1 & 1 & 1 & 1 & 1 & 1 & 1 & 1 & 1 & 1 & 1 & 1 & 0 \\
\hline 8 & oly chain activities & 0 & 1 & 0 & 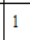 & 1 & 0 & 0 & 1 & 1 & 0 & 1 & 1 & 1 & 1 & 1 & 0 & 0 \\
\hline 9 & Elexbibity & 0 & 1 & 0 & 0 & 0 & 0 & 0 & 1 & 1 & 0 & 0 & 1 & 1 & 1 & 1 & 0 & 0 \\
\hline 10 & Benefit sharing & 0 & 0 & 1 & 1 & 0 & 1 & 1 & 0 & 0 & 1 & 1 & 1 & 1 & 1 & 1 & 0 & $1^{*}$ \\
\hline 11 & Joint Decision Making & 1 & 0 & 1 & 1 & 1 & 1 & 1 & 0 & 0 & 1 & 1 & 1 & 1 & 1 & 1 & 0 & 0 \\
\hline 12 & Organizational sulture & 0 & 0 & $1^{*}$ & 0 & 0 & 0 & 0 & 0 & 0 & 0 & 0 & 1 & 1 & 0 & 0 & 0 & 0 \\
\hline 13 & Orgamisational compatibility & 1 & 1 & 1 & 1 & 1 & 1 & 1 & 1 & 1 & 1 & 1 & 1 & 1 & 1 & 1 & 1 & 0 \\
\hline 14 & Resource sharing (integration) & 1 & 1 & 1 & 0 & 1 & 0 & 1 & 0 & 0 & 0 & 1 & 1 & 1 & 1 & 1 & 1 & 0 \\
\hline 15 & Top management suppert & . & 0 & 0 & 0 & 0 & 0 & 1 & 0 & 0 & 0 & 0 & 0 & 0 & 0 & 1 & 1 & 0 \\
\hline 16 & Technological readiness & 1 & 1 & $1^{*}$ & 0 & 1 & $1^{*}$ & 0 & 1 & 1 & 0 & 0 & 0 & 1 & 1 & $1^{*}$ & 1 & 0 \\
\hline 17 & Training & 1 & 1 & 1 & 1 & 1 & 1 & 1 & 1 & 1 & $1^{*}$ & 1 & 1 & 0 & 1 & 1 & 0 & 1 \\
\hline
\end{tabular}

TABLE VII.

ITERATION 1

\begin{tabular}{|c|c|c|c|c|}
\hline No. & Reachability set & Antecedent set & $\begin{array}{l}\text { Intersection } \\
\text { set }\end{array}$ & Level \\
\hline 1 & $1,2,3,4,5,7,8,12,13,14,15,17$ & $1,2,5,6,7,11,13,14,16,17$ & & \\
\hline 2 & $1,2,4,5,8,9,12,13,14,15,17$ & $1,2,5,7,8,13,14,16,17$ & & \\
\hline 3 & $3,4,11,12,13,14,15$ & $1,3,10,11,13,14,17$ & & \\
\hline 4 & $4,8,10,11,12,13,14,15$ & $1,2,3,4,5,6,7,8,10,11,13,17$ & & \\
\hline 5 & $1,2,4,5,8,9,12,13,14,15,16,17$ & $1,2,5,7,8,10,13,14,16,17$ & & \\
\hline 6 & $1,4,6,7,12,13,14,15$ & $6,7,10,11,13,17$ & & \\
\hline 7 & $\begin{array}{l}1,2,4,5,6,7,8,9,10,11,12,13,14,15, \\
16\end{array}$ & $1,6,7,10,11,13,14,15,17$ & & \\
\hline 8 & $2,4,5,8,9,11,12,13,14,15$ & $1,2,4,5,7,8,9,13,16$ & & \\
\hline 9 & $2,8,9,12,13,14,15$ & $2,5,7,8,9,13,16,17$ & & \\
\hline 10 & $3,4,6,7,10,11,12,13,14,15,17$ & $3,4,7,10,11,14,16,17$ & & \\
\hline 11 & $1,3,4,5,6,7,10,11,12,13,14,15$ & $3,4,6,7,8,10,11,13,14,17$ & & \\
\hline 12 & 12,13 & $1,2,3,4,5,6,7,8,9,10,11,12,13,14,17$ & 12,13 & I \\
\hline 13 & $\begin{array}{l}1,2,3,4,5,6,7,8,9,10,11,12,13,14,1 \\
5,16\end{array}$ & $1,2,3,4,5,6,7,8,9,10,11,12,13,14,16$ & & \\
\hline 14 & $1,2,3,5,7,11,12,13,14,15,16$ & $1,2,3,4,5,6,7,8,9,10,11,13,14,16,17$ & & \\
\hline 15 & $7,15,16$ & $\begin{array}{l}1,2,3,4,5,6,7,8,9,10,11,13,14,15,16, \\
17\end{array}$ & & \\
\hline 16 & $1,2,3,5,6,8,9,13,14,16$ & $3,5,6,7,13,14,15,16$ & & \\
\hline 17 & $1,2,3,4,5,6,7,8,9,11,12,14,15,17$ & $1,5,17$ & & \\
\hline
\end{tabular}

In the present case, the 17 enablers are presented in Tables 7-8. The level identification process of these enablers is completed in four iterations as shown in Tables 7-8.

TABLE VIII.

ITERATIONS 2-5

\begin{tabular}{|l|l|l|l|l|}
\hline No. & Reachability set & Antecedent set & Intersection set & Level \\
\hline 15 & $7,15,16$ & $\begin{array}{l}1,2,3,4,5,6,7,8,9,10,11,14,15,1 \\
6,17\end{array}$ & $7,15,16$ & II \\
\hline 3 & $3,4,11,14$ & $1,3,4,10,11,14,17$ & $3,4,11,14$ & III \\
\hline 4 & 8,10 & $1,2,5,6,8,10,17$ & 8,10 & IV \\
\hline 8 & $2,5,8,9$ & $1,2,5,8,9$ & $2,5,8,9$ & IV \\
\hline 9 & $2,8,9$ & $2,5,8,9,17$ & $2,8,9$, & IV \\
\hline 14 & $1,2,5$ & $1,2,5,6,8,9,1017$ & $1,2,5$ & IV \\
\hline 1 & 17 & 6,17 & 17 & V \\
\hline 2 & 17 & 17 & 17 & V \\
\hline 5 & 17 & 17 & 17 & V \\
\hline 6 & 6 & 6,17 & 6 & V \\
\hline 7 & 6 & 6,17 & 6 & V \\
\hline 10 & 17 & 17 & 17 & V \\
\hline 11 & 6 & 6,17 & 6 & V \\
\hline 13 & 6 & 6 & 6 & V \\
\hline 16 & 6 & 6 & 6 & V \\
\hline 17 & 6,17 & 17 & 17 & V \\
\hline
\end{tabular}

\section{V.BUILDING THE ISM MODEL}

The diagraph for interpretive structural modelling is drawn. Having identified the levels of the elements, the relations between the elements is drawn with the help of an arrow. The level I enablers are in the top level in the hierarchy. The enablers of the same level are kept on the same level of hierarchy [36]. The diagraphs give information about the hierarchy between the elements of enablers for the collaboration between logistics partners (see Fig. 2). It can be seen in Fig. 2 that the most important enablers (level I) are 'Common business goals' and 'Training'.

The purpose of Cross-Impact Matrix Multiplication Applied to the Classification analysis (MICMAC) is to analyse the drive power and dependence power of enablers. This is done to identify the key enablers that drive the system in various categories [18]. The variables are classified into four clusters (see Fig. 3). 


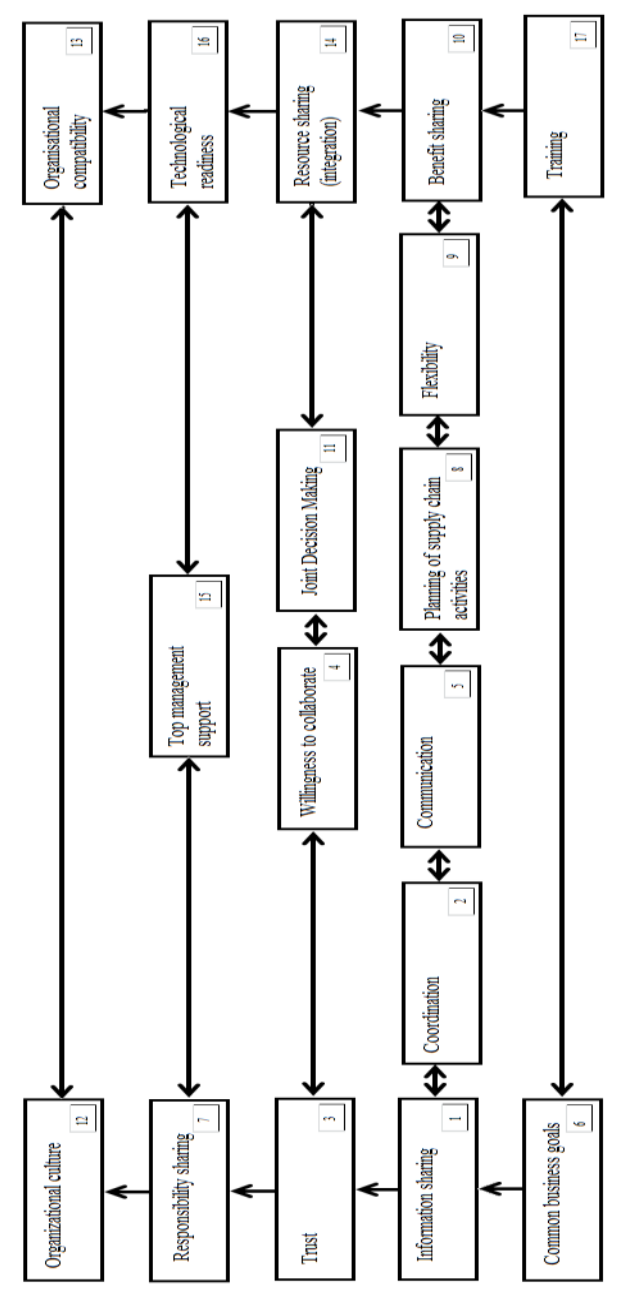

Fig. 2 The ISM based model for enablers for collaboration between logistics partners

\section{MICMAC ANALYSIS}

They have been classified into four categories:

- The first cluster consists of autonomous variables (Autonomous enablers). These enablers have a weak drive power and weak dependence. They are relatively disconnected from the system, with which they have few links, which may be very strong.

- The second cluster consists of the dependent variable (Linkage enablers). These have strong drive power as well as strong dependence. They are also unstable. Any action on them will have an effect on others and also a feedback effect on themselves.

- The third cluster has the linkage variables (Dependent enablers). This category includes those enablers which have a weak drive power but strong dependence power.

- The fourth cluster includes the independent variables (Independent enablers). These have a strong drive power but a weak dependence power. It is generally observed that an enabler with a very strong drive power, called the 'key enabler' falls into the category of independent or linkage enablers [18, 20, 24].

Enablers is constructed as shown in Fig. 3 (The driver power-dependence Matrix).

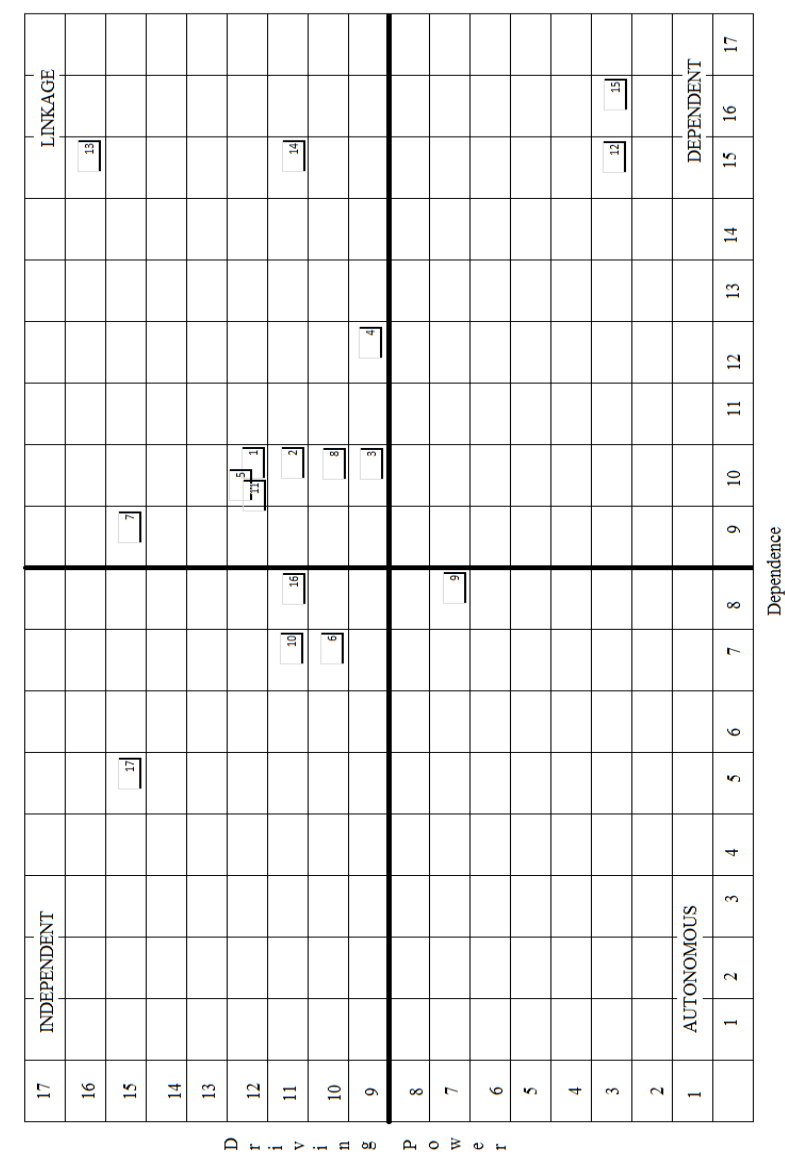

Fig. 3 Clusters of enablers in the implementation of collaboration between logistics partners

\section{DESCRIPTION OF THE MOST IMPORTANT IMPLEMENTATION ELEMENTS}

In this research, an ISM-based model has been developed to analyse the interactions among different enablers [18]. The main objective of this research is to analyse the effectiveness of various enablers which help in the implementation of collaboration between logistics partners. The methodology proposed here identifies the hierarchy of actions to be taken for handling different enablers' ability to implement sustainability collaboration between logistics partners.

The managers can gain insight into these enablers and understand their relative importance and interdependencies. The driver dependence diagram gives some valuable insight about the relative importance and interdependencies among the collaboration sustainability enablers between logistics partners.

Some of the important implications emerging from this study are as follows: Figure 10 shows that in Autonomous enabler is one enabler: 'Flexibility' (enabler 9). Autonomous 
enabler is weak driver and weak dependent and do not have much influence on the system.

Two enablers are Linkage enablers. Linkage enablers are 'Information sharing' (enabler 1), 'Coordination' (enabler 2), 'Trust' (enabler 3), 'Willingness to collaborate' (enabler 4), 'Communication' (enabler 5), 'Responsibility sharing' (enabler 7), 'Planning of supply chain activities' (enabler 8), 'Joint Decision Making' (enabler 11), 'Organisational compatibility' (enabler 13), 'Resource sharing (integration)' (enabler 14). They have a strong driving power as well as high dependencies [18]. If they are implemented in a proper way they can create a positive environment for the successful implementation of collaboration between logistics partners.

Enablers' 'Common business goals' (enabler 6), 'Benefit sharing' (enabler 10), 'Technological readiness' (enabler 16), and 'Training' (enabler 17) are Independent enablers. They have a strong driving power and weak dependency on other enablers.

'Organizational culture' (enabler 12) and 'Top management support' (enabler 15) are Dependent enablers. These enablers are weak drivers but strongly depend on one another. The managers should take special care to handle these enablers.

\section{CONCLUSIONS AND FUTURE WORKS}

This model proposed for the identification of enablers of sustainability collaboration between logistics partners can help in deciding the priority to take steps proactively. The results of this research can help in strategic and tactical decisions for a company wanting to create sustainability collaboration between logistics partners.

The main strategic decision relies on 'Common business goals' and 'Training'. These enablers, which are at the bottom of the ISM-based model and are the most important enablers that initiate strategic activities.

The analysis reveals that enablers 'Common business goals', 'Benefit sharing', 'Technological readiness' and 'Training' are ranked as Independent enablers as they possess the maximum driver power. This implies that these variables are key barriers in the successful implementation of sustainability collaboration between logistics partners. The most important among them are 'Common business goals' and 'Training'.

The ISM-based model provides a very useful understanding of the relationships among the enablers. The present model can be statistically tested with use of structural equation modelling (SEM) which has the ability to test the validity of such models [18].

\section{REFERENCES}

[1] L. Horvath, Collaboration: key to value creation in supply chain management, Supply Chain Management, Vol. 6, no. 5, 205-7, 2001. http://dx.doi.org/10.1108/13598540810860994

[2] T.M. Simatupang, R. Sridharan, The collaborative supply chain, Logistics Management (MCB UP Ltd) Vol. 13, pp. 15-30, 2002. http://dx.doi.org/10.1108/09574090210806333
[3] T.M Simatupang, A.C. Wright, R. Sridharan, Applying the Theory of Constraints to Supply Chain Collaboration, Supply Chain Management: An International Journal, Vol. 9, No. 1, pp. 57-70, 2004. http://dx.doi.org/10.1108/13598540410517584

[4] C. Jr. Langley, (2000), 7 Immutable laws of Collaborative Logistics.

[5] Adetiloye, Taiwo Olubunmi, Collaboration Planning of Stakeholders for Sustainable City Logistics Operations. Masters thesis, Concordia University, 2012.

[6] M.A. Barratt, Understanding the meaning of collaboration in the supply chain, Supply Chain Management, Vol. 9, no. 1, 30-34, 2004. http://dx.doi.org/10.1108/13598540410517566

[7] L. Cassivi, Collaboration planning in a supply chain, Supply Chain Management: An International Journal, Vol 11, no. 3, 249 -258, 2006. http://dx.doi.org/10.1108/13598540610662158

[8] Garner Group, Collaborative - commerce: The new arena for business applications, Technical Report, Gartner, Inc. Stamford, Connecticut, 1999.

[9] O.R. Ovalle, A.C. Márquez, The effectiveness of using ecollaboration tools in the supply chain: an assessment study with system dynamics." Purchasing and Supply Management, Vol. 9, 151163, 2003.

[10] M. Holweg, S. Disney, J. Holmström, J. Småros, Supply Chain Collaboration: Making Sense of the Strategy Continuum, European Management Journal, Vol. 23, no. 2, 170-181, 2005.

[11] R. Kale, P.T. Evers, M.E. Dresner, Analyzing private communities on internet - based collaborative transportation networks, Transportation Research E, Vol. 43: 21-38, 2007.

[12] J.A Muckstadt, D.H Murray, J.A. Rappold, D.E. Collins, Guidelines for Collaborative Supply Chain System Design and Operation, Technical report No. 1286, School of Operations Research and Industrial Engineering, College of Engineering, Cornel University ITHACA, NY 14853-3801, 2011.

[13] G. Zhou, Y.V. Hui, L. Liang, Strategic Alliance in Freight Consolidation, Transportation Research E, vol. 47, no. 1,pp. 18-29, 2011. http://dx.doi.org/10.1016/j.tre.2010.07.002

[14] A. Awasthi, K. Grzybowska, S. Chauhan, Goyal S K ., Investigating Organizational Characteristics for Sustainable Supply Chain Planning Under Fuzziness", Kahraman, Cengiz, Öztayși, Başar (eds.), Supply Chain Management Under Fuzziness, Studies in Fuzziness and Soft Computing 313, Springer- Ferlag Berlin Heidelberg 2014.

[15] J. Mula, D. Peidro, M. Díaz-Madroñero, E. Vicens, Mathematical programming models for supply chain production and transport planning, European Journal of Operational Research, Vol. 204, (3), pp. 377-390, 2010. http://dx.doi.org/10.1016/j.ejor.2009.09.008

[16] P. Sitek, J. Wikarek, Cost optimization of supply chain with multimodal transport, Federated Conference on Computer Science and Information Systems (FedCSIS), 2012, pp. 1111-1118.

[17] P. Sitek, J. Wikarek, A hybrid method for modeling and solving constrained search problems, Federated Conference on Computer Science and Information Systems (FedCSIS), 2013, pp.385-392.

[18] T. Raj, R. Shankar, M. Suhaib, (2008), An ISM approach for modelling the enablers of flexible manufacturing system: the case for India, International Journal of Production Research, Vol. 46, No. 24, pp. 6883-6912. http://dx.doi.org/10.1080/00207540701429926

[19] S. Bhattacharya, K. Momaya, K. C. Iyer, Enablers of sustaining competitiveness: a case of growth strategies of top international construction companies, Global business review, Vol. 10, No. 1, pp. 45-66, 2009. http://dx.doi.org/10.1177/097215090801000103

[20] S. Jharkharia, R. Shankar, IT enablement of supply chains: modeling the enablers, International Journal of Productivity and Performance Management, Vol. 53, Issue 8, pp. 700-712, 2004. http://dx.doi.org/10.1108/17410400410569116

[21] V. Ravi, R. Shankar, Analysis of interactions among the barriers of reverse logistics, Technological Forecasting and Social Change, Vol. 72, Issue 8, pp. 2005. http://dx.doi.org/10.1016/j.techfore.2004.07.002

[22] P. Charan, R. Shankar, R. K. Baisya, (2008), Analysis of interactions among the variables of supply chain performance measurement system implementation, Business Process Management Journal, Vol. 14, No. 4, pp. 512-529. http://dx.doi.org/10.1108/14637150810888055 
[23] K. Grzybowska, Modelling the barriers of global supply chain, Management of Global and Regional Supply Chain - research and concepts, K. Grzybowska, Publishing House of Poznan University of Technology, pp.41-58, 2011

[24] K. Grzybowska, Supply Chain Sustainability - analysing the enablers, Environmental issues in supply chain management - new trends and applications, P. Golinska, C. A.Romano (Eds.), Springer, pp. 25-40, 2012. http://dx.doi.org/10.1007/978-3-642-23562-7_2

[25] C.K Hahn, E.A. Duplaga, J.L. Hartley. Supply chain synchronization: lessons from Hyundai Motor Company, Vol. 30, Issue 4, pp. 32-45, 2000 .

[26] H. L. Lee, S. Whang, Information distortion in a supply chain, International Journal of Technology Management, Vol. 20, Issue 3-4, pp. 373-387, 2000.

[27] K. Grzybowska, G. Kovács, Logistics Process Modelling in Supply Chain - algorithm of coordination in the supply chain - contracting, 2014

[28] K. Grzybowska, "Creating trust in the supply chain”, New insights into supply chain, K. Grzybowska (ed.), Publishing House of Poznan University of Technology, pp. 9-21, 2010

[29] R. G. Richey, F. G. Adams, V.Dalela, Technology and Flexibility: Enablers of Collaboration and Time-Based Logistics Quality, Journal of Business Logistics, Issue 33, pp. 34-49, 2012. http://dx.doi.org/10.1111/j.0000-0000.2011.01036.x

[30] M. Hussain, Modelling the enablers and alternatives for sustainable supply chain management. Masters thesis, Concordia University, 2011.
[31] A. Agarwal, R. Shankar, M.K. Tiwari, Modeling agility of supply chain, Industrial Marketing Management, 36 (4), pp. 443-457, 2007, http://dx.doi.org/10.1016/j.indmarman.2005.12.004

[32] P. Swafford, S. Ghosh, N. Murthy, Achieving supply chain agility through IT integration and flexibility. International Journal of Production Economics, Vol. 116, pp. 288-297, 2008. http://dx.doi.org/10.1016/j.ijpe.2008.09.002

[33] D. R. Farris, A. P. Sage, On the use of interpretive structural modeling for worth assessment, Computers \& Electrical Engineering, Vol. 2, Issue 2-3, pp. 149-174, 1974. http://dx.doi.org/10.1016/00457906(75)90004-X

[34] M. D. Singh, R. Shankar, R. Narain, A. Agarwal, An interpretive structural modeling of knowledge management in engineering industries, Journal of Advances in Management Research, Vol. 1, No. 1, pp.28-40, 2003.

[35] J. Warfield, Societal Systems: Planning, Policy and Complexity, John Wiley \& Sons, Inc., New York, 1973.

[36] S. K. Sharma, B. N. Panda, S. S. Mahapatra, S. Sahu, Analysis of Barriers for Reverse Logistics: An Indian Perspective, International Journal of Modelling and Optimization, Vol. 1, No. 2, pp. 101-106, 2011. http://dx.doi.org/10.7763/IJMO.2011.V1.18

[37] N. Kumar, R. Prasad, R. Shankar, K. C. Iyer, Technology transfer for rural housing: An interpretive structural modeling approach, Journal of Advances in Management Research, Vol. 6, Issue 2, pp. 188-205, 2009. http://dx.doi.org/10.1108/09727980911007208 